\section{Human Immunodeficiency \\ S} Virus (HIV) and Hepatitis C Virus (HCV) in a Northern Alberta Population

\author{
Samantha L. Bowker, MSc ${ }^{1}$ \\ Colin L. Soskolne, $\mathrm{PhD}^{1}$ \\ Stan C. Houston, MD ${ }^{2}$ \\ Stephen C. Newman, MD, MSc ${ }^{1}$ \\ Gian S. Jhangri, MSc ${ }^{1}$
}

\section{ABSTRACT}

Objective: To describe the demographics and estimate the prevalence of hepatitis $\mathrm{C}$ virus (HCV) in a cohort of Human Immunodeficiency Virus (HIV) positive patients in Northern Alberta.

Methods: A cross-sectional (prevalence) study was performed on a cohort of HIV-positive patients. HCV testing was not widely available until December 1989, and the more sensitive, second generation immunoassay was not available until 1992. To reduce the effect of testing bias, we restricted consideration of HCV status to patients first seen January 1, 1992 onward.

Results: Forty-four percent of patients in the whole cohort were tested for HCV $(564 / 1,276)$ and $62 \%(505 / 809)$ of patients entered since January 1, 1992 were tested for HCV. During the period January 1, 1992-December 31, 1999, the prevalence of HCV in our cohort of northern Alberta HIV-positive patients was at least 37.9\% (307/809) and was $60.8 \%$ (307/505) among those who were tested for HCV in 1992 or later. The mean age of the coinfected group was 33.6 years, $66.1 \%$ were male, $91.2 \%$ were injection drug users (IDUs), $56.8 \%$ were Caucasian, and $40.0 \%$ were Aboriginal. A statistically significant difference was found between the HCV-negative cohort, the HCV co-infected cohort, and the HCVuntested cohort for the following variables: risk behaviour, gender, ethnic status, death, occurrence of an AIDS-defining illness $(p<0.0001)$, and mean baseline CD4 cell count $(\mathrm{p}=0.002)$.

Conclusion: A high proportion of the HIV-infected IDUs was co-infected with HCV. Compared to the HCV-negative group, the co-infected group appears to have had less advanced HIV disease. This is likely a reflection of more recent HIV infection in the HCV co-infected group.

La traduction du résumé se trouve à la fin de l'article.

1. Department of Public Health Sciences, University of Alberta, Edmonton, Alberta

2. Department of Medicine, University of Alberta, Edmonton

Correspondence and reprint requests: Colin L. Soskolne, 13-103 Clinical Sciences Building, University of Alberta, Edmonton, AB T6G 2G3, Tel: 780-492-6013, Fax: 780-492-0364, E-mail: colin.soskolne@ualberta.ca

Acknowledgements: The authors acknowledge the University of Alberta HIV Research Fund for their generous financial support. The HIV database has also been funded by the HIV program with support from the LCDC and the Capital Health Authority. This paper derives from the first author's Master of Science thesis at the University of Alberta, entitled "The Pathogenesis of Human Immunodeficiency Virus in a Cohort of Patients Co-infected with Hepatitis C Virus", 2001. ince the early 1980 s, when the Human Immunodeficiency Virus (HIV) pandemic began in Canada, there has been a steady decline in the proportion of incident HIV infections nationally among men who have sex with men (MSM), from over $80 \%$ during 1981 1983 , to $29.5 \%$ in 1996 , followed by an increase once again in 1999 to $38.4 \%$. In contrast, there has been a substantial increase in the proportion of incident HIV infections among injection drug users (IDUs), from less than $10 \%$ before 1986 , to $24 \%$ in $1987-1990$, and to $46.9 \%$ in 1996. ${ }^{1}$ However, there has been a recent decline in the proportion of newly-infected IDUs to $34.1 \%$ in 1999 . Thus, a large proportion of new HIV infections in Canada are occurring in IDUs, explaining the substantial and growing importance of HIV and hepatitis C virus (HCV) coinfection. In the Montreal drug user cohort study, the cumulative probability of HIV seroconversion was $33 \%$ for needle exchange program (NEP) users and 13\% for non-users. ${ }^{2}$ Furthermore, as treatment for HIV improves, liver disease accounts for an increasing proportion of morbidity and mortality in the HIV-infected.

$\mathrm{HCV}$ was first cloned in December 1989 , and is the cause of more than $90 \%$ of parenterally-acquired non- $A$, non-B hepatitis. ${ }^{3}$ Prior to 1990 , there was no test commercially available to detect HCV antibody in the population. Although a very small percentage of patients with histories of sexual exposure (1-10\%), household exposure (1-10\%), occupational exposure $(1-2 \%)$, or hemodialysis $(20 \%)$ have become infected with HCV, the highest rates of transmission are via parenteral routes. ${ }^{3-9}$ In Canada, transfusion of blood or blood products, transplantation of organs from infected donors, and sharing of contaminated needles among IDUs were the most efficient means for transmitting HCV. ${ }^{9-11}$ Since 1990, all blood donors in Canada have been screened for anti$\mathrm{HCV}$, virtually eliminating the possibility of infection via this route. ${ }^{12}$ IDU now represents the risk behaviour associated with the great majority of incident $\mathrm{HCV}$ infections in Canada. ${ }^{9,13,14}$

The prevalence of HCV in Canada is currently estimated to be approximately $0.8 \%(0.68 \%-0.94 \%)$, with $0.96 \%$ in males and $0.53 \%$ in females. ${ }^{15}$ Those in age groups $<5$ years, 6-14 years, 15-19 years, 
20-39 years, 40-64 years, and 65+ were estimated to have a prevalence of $0.2 \%$, $0.05 \%, 0.10 \%, 1.51 \%, 0.75 \%$, and $0.6 \%$, respectively. ${ }^{9}$ Health Canada estimates the prevalence of HCV in Alberta in 1999 to be $0.91 .^{16}$ The authors of the Vancouver injecting drug use study report HIV and HCV prevalence rates of $23 \%$ and $88 \%$, respectively, in their cohort of IDUs. ${ }^{17}$ There are currently no published estimates of the prevalence of HCV in HIV-infected persons in Canada.

The objectives of this study were to examine the prevalence of HCV in a cohort of HIV-positive patients in a Northern Alberta population and to describe the demographic characteristics of this population.

\section{METHODS}

\section{Database}

This study makes use of an existing database of HIV-infected patients from 1979. The database contains information on all patients who have ever been seen for HIV infection at the University of Alberta Hospital (UAH) and the Sexually Transmitted Disease (STD) Clinic sites, regardless of whether they were initially diagnosed in Alberta. The manner in which the data were collected has been previously described. ${ }^{18}$

The database is believed to contain the majority of HIV-infected patients in northern Alberta. It is impossible to know the exact proportion of HIV-positive patients the database has captured. However, HIV patient care in northern Alberta is provided almost exclusively by members of the Division of Infectious Diseases in Edmonton, and hence the database is deemed quite complete. There are no physicians or groups providing care to significant numbers of $\mathrm{HIV}$-infected patients who do not share information and, in most cases, care of the patients with members of the Division of Infectious Diseases. The Laboratory generally asks about the involvement of Division members in a patient's care when CD4 cell counts or viral load measurements are requested, and the only two pharmacies that dispense antiretroviral drugs apply a similar policy. Therefore, most patients with a diagnosis of HIV infection and virtually all those receiving care for HIV

\section{TABLE I}

Demographic Characteristics of the HIV Study Population:

January 1, 1992-December 31, 1999

\begin{tabular}{|c|c|c|c|}
\hline & $\begin{array}{l}\text { HCV negative } \\
(\mathrm{N}=198)\end{array}$ & $\begin{array}{l}\text { HCV positive } \\
(\mathrm{N}=307)\end{array}$ & $\begin{array}{l}\text { HCV unknown } \\
(N=304)\end{array}$ \\
\hline \multicolumn{4}{|l|}{ Gender, n (\%)* } \\
\hline Male & $145(73.2)$ & $203(66.1)$ & $247(81.3)$ \\
\hline Female & $53(26.8)$ & $104(33.9)$ & $57(18.8)$ \\
\hline Age, mean $(\mathrm{SD}) \dagger$ & $35.4(11.9)$ & $33.6(8.3)$ & $34.2(10.6)$ \\
\hline \multicolumn{4}{|l|}{ Risk Behaviour, n (\%)* } \\
\hline MSM & $67(33.8)$ & $9(2.9)$ & $161(53.0)$ \\
\hline Heterosexual & $83(41.9)$ & $9(2.9)$ & $69(22.7)$ \\
\hline Injection drug user & $39(19.7)$ & $280(91.2)$ & $54(17.8)$ \\
\hline Transfusion or vertical transmission & $9(4.5)$ & $9(2.9)$ & $20(6.6)$ \\
\hline \multicolumn{4}{|l|}{ Ethnic Status, n (\%)* } \\
\hline Aboriginal & $48(25.7)$ & $112(40.0)$ & $55(19.1)$ \\
\hline Caucasian & $110(58.8)$ & $159(56.8)$ & $199(69.1)$ \\
\hline Other $\ddagger$ & $29(15.5)$ & $9(3.2)$ & $34(11.8)$ \\
\hline Baseline CD4 Count, mean (SD)§ & $370(374)$ & $483(325)$ & $399(431)$ \\
\hline Dead, $\mathrm{n}(\%) \|$ & $16(8.1)$ & $20(6.5)$ & $73(24.0)$ \\
\hline AIDS-defining illness, n (\%)*开 & $57(28.8)$ & $41(13.4)$ & $110(36.2)$ \\
\hline \multicolumn{4}{|c|}{$\begin{array}{l}\text { * Significant difference between the HCV negative cohort }(n=198) \text {, the HCV co-infected cohort } \\
(n=307) \text {, and the HCV untested cohort }(n=304) \text { for gender, risk behaviour, ethnic status, death, } \\
\text { and AIDS-defining illness, } p<0.0001 \text {. }\end{array}$} \\
\hline \multicolumn{4}{|c|}{$\dagger$ Age is based on age when first seen. } \\
\hline \multirow{3}{*}{\multicolumn{4}{|c|}{$\begin{array}{l}\ddagger \text { "Other" corresponds to Black, Hispanic, South Asian, and Oriental. } \\
\S \text { Significant difference between the HCV-negative cohort }(n=198) \text {, the HCV co-infected cohort } \\
\text { ( } n=307) \text {, and the HCV-untested cohort }(n=304) \text { for mean baseline CD4 count, } p=0.002 \text {. } \\
\text { II Dead prior to December 31, } 1999 \text {. }\end{array}$}} \\
\hline & & & \\
\hline & & & \\
\hline \multicolumn{4}{|l|}{$\begin{array}{l}\text { ๆ An AIDS-defining illness is defined acco } \\
\text { veillance case definition. }{ }^{22}\end{array}$} \\
\hline
\end{tabular}

infection are included in the HIV database. The number of individuals with HIV infection who have not been diagnosed is, of course, unknown. A seroprevalence study in two Edmonton Emergency departments, both of which serve populations at high risk both of HIV infection and of not accessing regular preventive care, found that $<20 \%$ of HIV-infected individuals had no previous evidence of a diagnosis. ${ }^{19}$

A total of 1,276 HIV-positive patients were in the database as of December 31 , 1999, of whom 564 had been tested for HCV (44.2\%). The decision to order $\mathrm{HCV}$ testing was made by the attending physician in each case, based on the physician's estimate of the patient's HCV risk. Injection drug users and patients who received blood transfusions prior to the introduction of HCV screening of the blood supply were therefore most likely to be tested for HCV.

\section{Study design}

A cross-sectional (prevalence) study was performed using the abovementioned database. There were no exclusion criteria for entry into the HIV database. The major objective of the study was to examine the prevalence of HCV among people infected with HIV. The University of Alberta Research Ethics Board approved the establishment of the HIV database in the early 1990s.

\section{Statistical analyses}

HCV testing was not widely available until December 1989, and the more sensitive, second generation immunoassay was not available until 1992. In the early testing era for HCV (1990-1992), false-negative tests were more likely, but more importantly, a much smaller proportion of newly entered patients in the database were tested for $\mathrm{HCV}$ compared to those entered more recently. Therefore, to reduce the effect of testing bias, we restricted consideration of HCV status to January 1992 onward. Thus, the table and graphs depicting coinfected individuals include only those patients first seen since January 1, 1992. Chi-square tests were used to compare proportions and the independent samples t-test was used to compare means. All analyses were performed using the statistical software package SPSS 9.0.

\section{RESULTS}

There were $564 / 1,276(44.2 \%)$ patients in the whole cohort and 505/809 (62.4\%) of those entered since January 1, 1992 who were tested for HCV. Table I provides the demographic characteristics for the $\mathrm{HCV}$ co-infected group $(\mathrm{N}=307)$, the $\mathrm{HCV}$ negative group $(\mathrm{N}=198)$, and the non-tested group $(\mathrm{N}=304)$ of HIV patients. During 1992-1999, the prevalence of HCV in our cohort of northern Alberta HIV-positive 


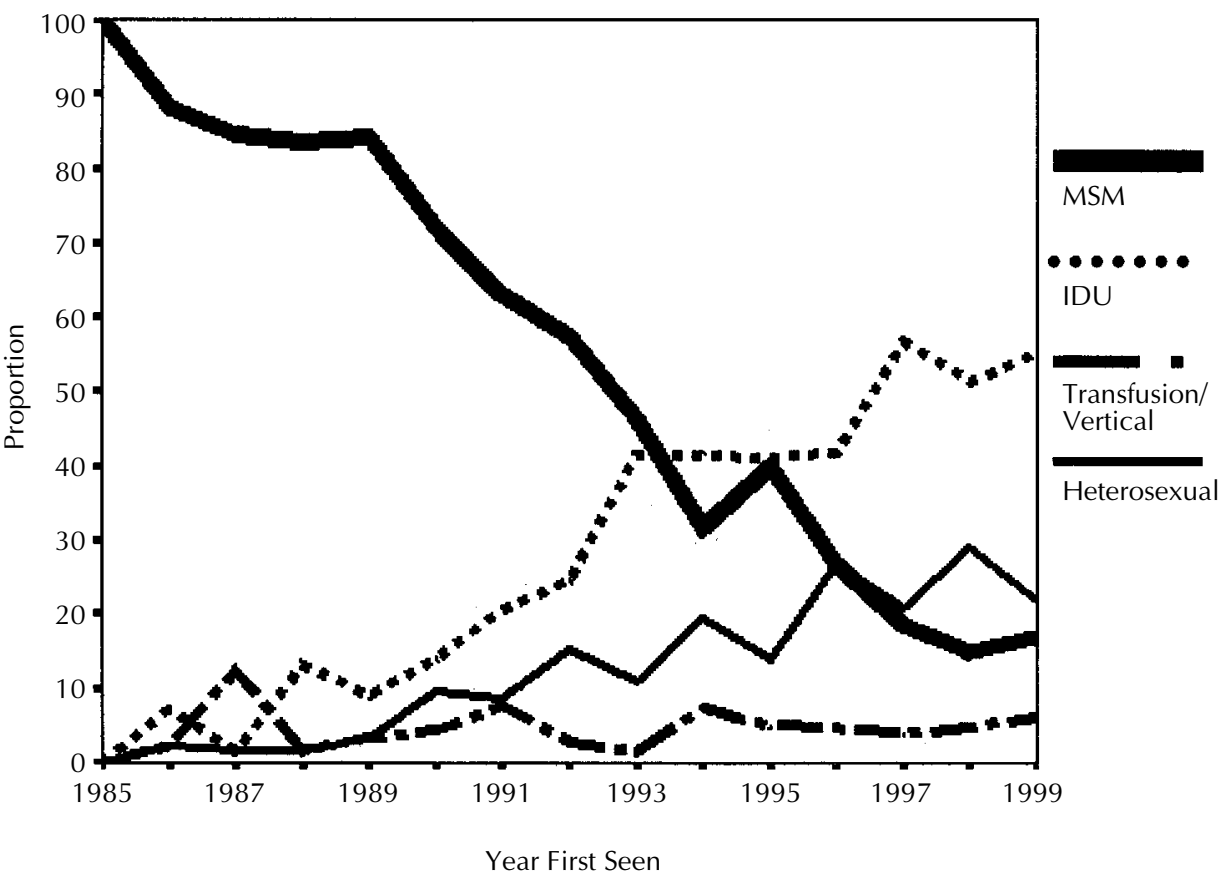

Figure 1. Proportion of HIV-positive patients in the entire cohort, according to year first seen and by risk behaviour, 1985-1999

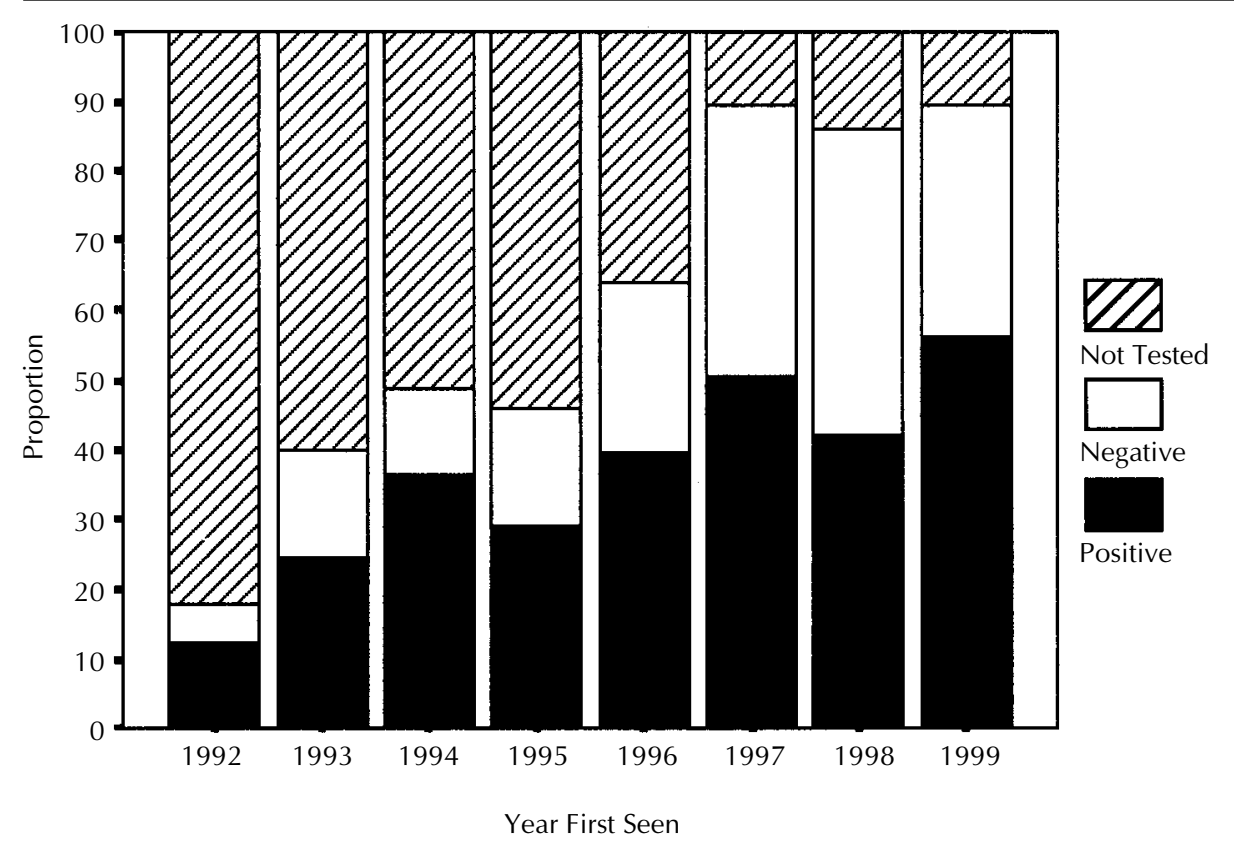

Figure 2. Distribution of hepatitis $\mathrm{C}$ antibody test results in the entire cohort, 1992-1999

patients was at least $37.9 \%(307 / 809)$ and was $60.8 \%(307 / 505)$ among those who were tested for $\mathrm{HCV}$.

Co-infection was significantly associated with IDU behaviour, female sex, and Aboriginal ethnic origin, and was negatively associated with death and the development of an AIDS-defining illness $(\mathrm{p}<0.0001)$. The proportion who were female was higher among those who were HCV-positive (33.9\%) than in either the
HCV-negative $(26.8 \%)$ or untested (18.8\%) patients.

Of the 809 patients in the January 1, 1992-December 31, 1999 cohort, 373 (46.1\%) reported a history of IDU. Since IDU was a major criterion for HCV testing, it is not surprising that $91.2 \%$ (280/307) of all co-infected patients were IDUs. This can be compared to the patients who were HCV-negative and HCV-untested, a large proportion of whom $(75.7 \%$ and $75.7 \%$, respectively) indicate MSM or heterosexual transmission. Only $19.7 \%$ and $17.8 \%$ were accounted for by IDU in the HCV-negative and HCVuntested groups, respectively. There was a large proportion of Aboriginals (40.0\%) among the co-infected patients, compared to patients who were $\mathrm{HCV}$-negative $(25.7 \%, \mathrm{p}<0.0001)$. However, Caucasian ethnicity still predominated among coinfected patients $(56.8 \%)$ ). A smaller number of co-infected patients (13.4\%) had an AIDS-defining illness, and $93.5 \%$ of coinfected people were alive as of the end of 1999, compared to HCV-negative patients (28.8\% of whom had an AIDS-defining illness, and $91.9 \%$ of whom were still alive, $\mathrm{p}<0.0001)$. Furthermore, co-infected patients had a significantly higher $(\mathrm{p}=0.002)$ mean baseline CD4 cell count (483) compared to the HCV-negative group (370).

Figure 1 shows the proportion of HIVpositive patients in the entire cohort, according to year first seen and by risk behaviour. There was a sharp decrease in the proportion of MSM from 1985-1999, whereas there was a steady increase in the proportion of new patients in whom IDU was the likely risk behaviour. Figure 2 shows the distribution of HCV antibody test results in the entire cohort, 19921999. Since 1992, there had been an increasing trend in the number of individuals being tested for HCV in the northern Alberta database. In 1992, only $17.9 \%$ (19/106) of patients were being tested; however, by $1999,90.0 \%(86 / 96)$ of patients were tested, of whom $62.8 \%$ (54/86) were positive.

\section{DISCUSSION}

During the period 1992-1999, the prevalence of HCV in our cohort of northern Alberta HIV-positive patients was at least $37.9 \%$ (307/809). Among those tested for $\mathrm{HCV}$, the prevalence was found to be $60.8 \%(307 / 505)$. Not surprisingly, the majority of those tested were IDUs. After 1992, when HCV testing became more widely implemented, the thoroughness and accuracy of a risk history obtained by an HIV specialist physician became the main determinant of the proportion of $\mathrm{HCV}$ infected individuals who were actually tested. 
There were $373 / 809$ (46.1\%) patients in the cohort that reported a history of IDU (Table I). It has been reported in the literature that up to $90 \%$ of IDUs are positive for antibodies to $\mathrm{HCV}{ }^{20,21}$ Therefore, it was somewhat surprising that only $75.1 \%$ (280/373) of patients who reported a history of IDU in the cohort were infected with HCV. Among those IDUs tested for HCV, 87.8\% (280/319) were positive. If the 54 patients who were IDUs and who were not tested for HCV had been tested, it is likely that a large proportion would have been HCV-positive. In addition, while only $62.4 \%$ of the entire cohort had been tested for HCV, a substantial proportion of the remaining 304 not tested for HCV had died by the end of the study period (24.0\%).

Compared to patients who were HCVnegative, the co-infected group had a smaller proportion of patients diagnosed with an AIDS-defining illness and a larger proportion of patients who were still alive (Table I). From Figures 1 and 2, patients who were infected with HIV in the 1980s and early 1990s were mostly MSM, at low risk for $\mathrm{HCV}$, whereas patients infected with HIV more recently (after 1993) were more often IDUs and HCV-positive. Coinfection of $\mathrm{HIV}$ with $\mathrm{HCV}$ increased in more recent years, because of the recent shift in the local HIV epidemic to IDUs. Therefore, on average, co-infected patients had HIV disease of a shorter duration (consistent with higher CD4, fewer AIDSdefining illnesses and fewer deaths). In addition, the emergence of HIV and HCV co-infection coincided with significant improvements in HIV therapy (HAART became generally available in Edmonton in late 1996). This points to the need to consider length of time under observation (i.e., survival analysis). In the thesis upon which this paper is based, ${ }^{18}$ a multivariate analysis was used to identify factors independently associated with HCV positivity.

The main limitation of this study is the high proportion of patients for whom HCV results were unavailable. Information pertaining specifically to IDU behaviour such as the type of drug injected, the frequency of injection, needle sharing and other injecting behaviours - and social factors such as homelessness were not captured in the database. These are important variables that should be considered in future studies. Another significant limitation is the non-systematic application of $\mathrm{HCV}$ testing; not everybody was tested for $\mathrm{HCV}$ and non-testing was not random. The strong tendency of clinicians to test for HCV when they elicited or suspected a history of IDU behaviour means that $\mathrm{HCV}$ would have been under-estimated in those who were not IDUs or who did not disclose such a history. This information was obtained in all cases by experienced HIV physicians, who established strong personal relationships with their patients over time, thus likely minimizing the latter effect.

This study demonstrates that between 1992 and 1999, HIV and HCV co-infection was a large problem in Northern Alberta. Another implication of the study findings is that all HIV-positive patients should have $\mathrm{HCV}$ testing recommended, a practice that has been adopted since the study period. Since the main route of $\mathrm{HCV}$ transmission is IDU and a dominant route of HIV transmission is also through IDU, expansion of preventive activities, including harm reduction measures such as needle exchange, needs to be reinforced. ${ }^{9}$ While NEP are essential, they should be considered one component of a comprehensive program including counselling, support and education. ${ }^{17}$ Clear and evidence-based information should be provided to co-infected patients about prevention of transmission from these individuals, with special attention to IDUs. ${ }^{8}$ Another implication of these findings is for prognosis and care. There is an urgent need for efficacious treatment for liver disease in these patients, and for adaptations to provisions of care to respond to the changing patient population.

\section{REFERENCES}

1. Bureau of HIV/AIDS, STD and TB Update Series, Laboratory Centre for Disease Control. HIV/AIDS Epi update. Available on-line at: www.hc-sc.gc.ca/h pb/lcdc/bah/epi/ estima_e.html, November 2000.

2. Bruneau J, Lamothe F, Franco E, Lachance N, Desy M, Soto J, et al. High rates of HIV infection among injection drug users participating in needle exchange programs in Montreal: Results of a cohort study. Am J Epidemiol 1997;146(12):994-1002.

3. Van der Poel CL, Cuypers HR, Reesink HW. Hepatitis C virus six years on. Lancet 1994;344(8935):1475-79.

4. Boyer N, Marcellin P, Degott C, Degos F, Saimot AG, Erlinger S, et al. Recombinant Interferon-a for chronic hepatitis $\mathrm{C}$ in patients positive for antibody to human immunodeficiency virus. I Infect Dis 1992;165(4):723-26.

5. Brettler DB, Alter HJ, Dienstag JL, Forsberg AD, Levine $\mathrm{PH}$. Prevalence of hepatitis $\mathrm{C}$ virus antibody in a cohort of hemophilia patients. Blood 1990;76(1):254-56

6. Brettler DB, Mannucci PM, Gringeri A, Rasko JE, Forsberg AD, Rumi MG, et al. The low risk of hepatitis $\mathrm{C}$ virus transmission among sexual partners of hepatitis $\mathrm{C}$ infected haemophiliac males: An international multicenter study. Blood 1992;80(2):540-43.

7. Huet C, Dabis F, Saillour F, Trimoulet P, Morlat P, Rispal P, et al. Multicenter study of intrafamilial transmission of hepatitis $C$ virus in human immunodeficiency virus infection. Gastroenterol Clin Biol 2000;24(6-7):611-17.

8. Zarski JP, Leroy V. Counselling patients with hepatitis C. J Hepatol 1999;31 Suppl 1:136-40.

9. Zou S, Tepper M, Giulivi A. Current status of hepatitis C in Canada. Can J Public Health 2000;91(Suppl. 1):S10-S15.

10. Mele A, Tosti ME, Marzolini A, Moiraghi A, Ragni P, Gallo G, et al. Prevention of hepatitis C in Italy: Lessons from surveillance of type-specific acute viral hepatitis. SEIEVA Collaborating Group. J Viral Hepatol 2000;7(1):30-35.

11. Conry-Cantilena C, Van Raden M, Gibble J, Melpolder J, Shakil AO, Viladomiu L, et al. Routes of infection, viremia, and liver disease in blood donors found to have hepatitis $\mathrm{C}$ virus infection. N Engl J Med 1996;334(26):1691-96.

12. Alter MJ. Epidemiology of hepatitis C. Hepatology 1997;26(3 Suppl 1):62S-65S.

13. Kaldor JM, Dore GJ, Correll PK. Public health challenges in hepatitis $\mathrm{C}$ virus infection. J Gastroenterol Hepatol 2000;15 Suppl:E83-90.

14. Murphy EL, Bryzman SM, Glynn SA, Ameti DI, Thomson RA, Williams AE, et al. Risk factors for hepatitis $\mathrm{C}$ virus infection in United States blood donors. NHLBI Retrovirus Epidemiology Donor Study (REDS). Hepatology 2000;31(3):756-62.

15. Remis R, Hogg R, Krahn MD, et al. Estimating the number of blood transfusion recipients infected by hepatitis C virus in Canada, 1960-85 and 1990-92. Report to Health Canada, June 1998

16. PPHB Surveillance. Disease Surveillance: Notifiable Diseases On-Line. http://www.hcsc.gc.ca/pphb-dgspsp/surveillance_e.html September 2000.

17. Strathdee SA, Patrick DM, Currie SL, Cornelisse PG, Rekart ML, Montaner JS, et al. Needle exchange is not enough: Lessons from the Vancouver Injecting Drug Use Study. AIDS 1997;11(8):F59-65.

18. Bowker SL. The pathogenesis of human immunodeficiency virus in a cohort of patients co-infected with hepatitis $C$ virus [thesis]. Edmonton, Alberta: University of Alberta, 2001.

19. Houston S, Rowe B, Mashinter L, Preiksaitis J, Joffe M, Mackey D, et al. Anonymous unlinked seroprevalence of HIV and hepatitis C in two emergency departments - using patient databases to distinguish previously diagnosed cases. XIII International AIDS Conference. Durban, South Africa, July 9-14, 2000. Abstract Number MoPeC2411.

20. Bierhoff E, Fischer HP, Willsch E, Rockstroh J, Spengler U, Brackmann $\mathrm{HH}$, et al. Liver histopathology in patients with concurrent chronic hepatitis C and HIV infection. Virchows Arch 1997;430(4):271-77.

21. Cribier B, Rey D, Schmitt C, Lang JM, Kim A, Stoll-Keller F. High hepatitis $\mathrm{C}$ viraemia and impaired antibody response in patients co-infected with HIV. AIDS 1995;9(10):1131-36.

22. Castro KG, Ward JW, Slutsker L, et al. 1993 Revised Classification System for HIV Infection and Expanded Surveillance Case Definition for AIDS Among Adolescents and Adults. From the 
National Centre for Infectious Diseases of HIV/AIDS, Centers for Disease Control and Prevention, Atlanta, GA 1993;17:802-10.

Received: August 21, 2002

Revise/reconsider: December 13, 2002

Revised manuscript from author: September 2, 2003

Accepted: October 24, 2003

\section{RÉSUMÉ}

Objectif : Décrire l'évolution démographique et estimer la prévalence du virus de l'hépatite C (VHC) au sein d'une cohorte de patients du nord de l'Alberta séropositifs pour le virus de l'immunodéficience humaine $(\mathrm{VIH})$.

Méthode : Étude transversale (de prévalence) menée auprès d'une cohorte de patients séropositifs pour le VIH. Puisque le test de dépistage du VHC n'était pas généralement disponible avant décembre 1989, et que l'immuno-essai de deuxième génération, plus sensible, ne l'a été qu'en 1992, nous avons uniquement tenu compte de l'état sérologique VHC des patients vus à partir du $1^{\text {er }}$ janvier 1992, afin de réduire le biais associé aux tests.

Résultats : Quarante-quatre p. cent des patients de toute la cohorte avaient subi un test de dépistage du VHC (564/1 276), et $62 \%$ (505/809) des patients vus depuis le $1^{\text {er }}$ janvier 1992. Entre le $1^{\text {er }}$ janvier 1992 et le 31 décembre 1999, la prévalence du VHC au sein de la cohorte était d'au moins $37,9 \%(307 / 809)$, et de $60,8 \%(307 / 505)$ chez les patients ayant subi un test de dépistage du VHC à partir de 1992. Le groupe co-infecté par le VIH et le VHC avait un âge moyen de 33,6 ans; il était composé à 66,1\% d'hommes, à 91,2\% d'utilisateurs de drogues injectables (UDI), à $56,8 \%$ de Blancs et à $40 \%$ d'Autochtones. Nous avons constaté des différences significatives (entre la cohorte des patients séronégatifs pour le VHC, celle des patients co-infectés et celle qui n'avait pas subi de test de dépistage du VHC) à l'égard des variables suivantes : la propension à prendre des risques, le sexe, l'origine ethnique, le décès, la fréquence d'une maladie définissant le sida $(p<0,0001)$ et la concentration moyenne initiale de lymphocytes CD4 $(p=0,002)$.

Conclusion : Une forte proportion d'UDI infectés par le VIH étaient co-infectés par le VHC. Comparé au groupe séronégatif pour le $\mathrm{VHC}$, le groupe co-infecté semblait être à un stade moins avancé du VIH. Cela traduisait sans doute des infections à VIH plus récentes dans le groupe coinfecté. 